\title{
Testing Absolute PPP Hypothesis for Twenty Countries through the Skeleton from a SETAR Model: some New Evidence*
}

\section{Teste para a Hipótese da Paridade Absoluta da Taxa de Câmbio: Análise a partir do Skeleton de um Modelo SETAR}

\author{
André de Mattos Marques** \\ Erik Alencar de Figueiredo***
}

\begin{abstract}
In this study, the long run PPP hypothesis was tested considering real effective exchange rate dataset for twenty countries provided by the International Monetary Fund (IMF). By focusing on a nonlinear approach, the study tests IMF monthly dataset for specific nonlinearity. Additionally, the study presents a method to estimate the value that real exchange rate may converge in the long run. Linear and nonlinear cases were distinguished by the Hansen's test. The Self-Exciting Threshold Autoregressive (Setar) model was applied to estimate potential thresholds to indicate the states turning points of the countries competitiveness. Results suggest that real exchange rate for thirteen countries are highly nonlinear and subjected to regime switching. The asymptotic stability analysis guarantees the data stationarity behavior. Absolute PPP hypothesis was supported in five out of thirteen cases. In these few cases the real exchange rate converges to a stable equilibrium not far from the value predicted by the PPP hypothesis.
\end{abstract}

Keywords: Purchasing power parity. Real exchange rate. Nonlinearity.

Resumo: A hipótese da paridade do poder de compra (PPP) absoluta foi testada a partir de uma base de dados mensal para vinte países fornecida pelo Fundo Monetário Internacional. O estudo apresenta uma metodologia capaz de estimar o valor de equilíbrio para a taxa de câmbio real efetiva com dinâmica não linear e determinar sua estacionariedade. O número de regimes necessários para descrever o processo autorregressivo foi determinado pelo teste de Hansen. O modelo Threshold Autoregressive Self-Exciting (SETAR) foi estimado para determinar potenciais limiares que indicam mudanças de regime na competitividade dos países. Os resultados sugerem que a taxa de câmbio real efetiva de treze países apresenta dinâmica não linear com mudanças de regime. A análise de estabilidade assintótica a partir do skeleton sugere a estacionariedade dos dados. A hipótese da PPP absoluta foi corroborada em cinco dos treze casos. No geral, a taxa de câmbio real efetiva geralmente converge para um equilíbrio estável não muito distante do valor previsto pela hipótese da PPP absoluta.

Palavras-chave: paridade do poder de compra; taxa de câmbio real; não linearidade. JEL Classification: F31; F41.

\footnotetext{
* The authors are grateful to professor Vinicius Aguiar de Souza by its comments and helpful suggestions in an earlier draft of this paper. We are in debt with two anonymous referees of the journal. All remaining errors are only responsibility of the authors.

** PhD. Professor of Economics at Federal University of Paraiba, Brazil E-mail: 00094751@ufrgs.br

$* * * \quad$ PhD. Professor of Economics at Federal University of Paraiba, Brazil and CNPQ Researcher. E-mail: eafigueiredo@gmail.com
} 


\section{1 lntrodução}

Since the adoption of flexible exchange rate regime by different countries in the early 1970s, the hypothesis of purchasing power parity and the law of one price have been the subject of a large empirical debate employing different methodologies and databases. Despite its great importance in macroeconomics, the subject still is a matter of controversy because no agreement emerged concerning the empirical validity of its assumptions.

A wide variety of models just assume the purchasing power parity (OBSTFELD; ROGOFF, 1996) and their broad applications are well known, i.e., the equilibrium real effective exchange rate may be used to the choice of initial exchange rate to a newly independent country, to forecast average and long-term real exchange rate, comparing international incomes, e.g., wages and prices which are expressed in different units of measure.

The law of one price states that after a conversion by the exchange rate a product sold in different countries must have the same selling price in different currencies. Price differentials observed after conversion would be eliminated by the arbitrage promoted by the economic agents. Aggregating the different goods and services (values), the corollary of the law of one price concludes that the real exchange rate should converge to values close to unity in the long run, resulting in the hypothesis of the purchasing power parity (PPP). In its relative version, the variations in the real exchange rate should follow the same direction, i.e., the direction of the inflation differential between countries. In the absolute version, the real exchange rate would be constant in the long run and its value would be the central unit.

Despite the clarity with which the hypothesis is formulated, referring explicitly to the value that the real exchange rate would take over in the long run (in its absolute version), several authors merely interpret the weak stationarity of the real exchange rate as evidence of the PPP. For example, after applying the general test Dickey-Fuller (GLS) due to Elliot, Rothenberg and Stock (1996), using data for the real exchange rate to test the null of unit root hypothesis, Taylor (2002) concludes that his results provide a powerful support for the PPP hypothesis in the twentieth century in a sample of 20 countries. Additionally, Divino, Teles and Andrade (2009) and Kim and Lima (2010) are other examples of recent works using this interpretation as empirical evidence to validate the hypothesis of PPP.

To verify this theoretical assumption, more formal tests were used which generally lie within the unit root approach. Moreover, the specification of the model (with or without trend, with or without structural changes), the time window and the employed database also vary among them. In general, the main objective of these studies was to verify the property of mean reversion of the real exchange rate, 
for any arbitrary average, including values close to unity postulated by the PPP. The weak stationarity of the series was consider as evidence in favor of the PPP, but the specific value for which the real exchange rate could converge in the long run was not subject to examination. ${ }^{1}$ Another source of uncertainty in this methodology is due to the low power of these tests (TAYLOR; TAYLOR, 2004).

In this sense, the central opposition to the above mentioned methodology is that, not considering the power problem of these tests, they fail to report to which value the real exchange rate would converge in the long run. Thus, the weak stationarity of a time series is only necessary but not a sufficient condition to corroborate empirically the hypothesis of PPP. This opposition has emerged in a large survey of the literature. For Taylor and Taylor (2004, p. 142):

[...] mean reversion in only a necessary condition for long-run PPP: to ensure long-run absolute PPP, we should have to know that the mean toward which it is reverting is in fact the PPP real exchange rate. Still, since much of this research has failed to reject the hypothesis that even this necessary condition does not hold, this has not in general been an issue.

This work adds two contributions to this literature. First, after a detailed search in the leading journals, ${ }^{2}$ including The Journal of Economic Perspectives, no publication was found which solve the problem posed by Taylor and Taylor (2004). Most of works tend to concentrate on half-life calculation or mean reversion problem by completely avoiding face the issue on the value to which real effective exchange rate may reach in the long run. ${ }^{3}$ In this respect, we are able to inform the equilibrium value of real exchange rates prevailing at long run, so the monetary authority may use this information in advance and adjust the interest rate pegged accordingly.

Second, our methodology accommodates very well the real effective exchange rate behavior in $65 \%$ of our sample of 20 countries. Sollis, Leybourne and Newbold (2002) analyzed monthly observations ranging from April 1973 to November

$1 \quad$ This problem cannot be solved by more sophisticated tests, like the unit root test for a Setar model developed by Kapetanios and Shin (2006) or Sandberg and Changli (2005), neither Estar, LSTAR, or Markov Switching approaches, since these models are not related to the concept of skeleton which is the method to infer the equilibrium value of real exchange rate in this paper. The skeleton is a concept theoretically valid only for SETAR models designed to test and evaluate their asymptotic stability (CRYER; CHAN, 2008). Chan and Tong (1985) showed that under some mild conditions, a Setar model is asymptotically stationary if its skeleton is stable. This implies, with some regularity conditions, stronger property of ergodicity.

2 Beyond The Journal of Economic Perspectives, the authors examined The Journal of Political Economy, The Journal of Economic Literature, The Journal of Applied Econometrics, The Journal of Money, Credit, and Banking and The Journal of Business 8 Economic Statistics.

3 See, for example, Cerrato, Hyunsok and MacDonald (2010), Shintani (2006) and Rossi (2006). 
1997 on 17 real exchange rates of industrialized countries. Its results demonstrate empirically that estimates show stronger mean reversion when the real exchange rate is below the mean than when it is above. This type of result can be well accommodated in our threshold model. For policy makers, the importance of this issue relies upon the intervention policy of central banks.

According with Sollis, Leybourne and Newbold (2002), this asymmetric real exchange rate adjustment, characterized by large and persistent deviations from PPP long run value is explained by a reactive behavior from the central banks via monetary intervention. The reason is that, since the loss of competitiveness implies a large and persistent deficit in net exports in the long run, monetary authorities often make policy decisions to adjust the real exchange rate towards its long run value via monetary policy when the exchange rate is overvalued.

This explains why the velocity of adjustment towards mean is faster when exchange rate is below its long run value than when it is above of it. The problem at hand is that central banks never know exactly with certainty what may be this value in the long run. Thus, taking the question above in a deeper scrutiny, our work adds some useful contribution about the observed value of real effective exchange rate for a number of countries and for the policy decisions emanated from central banks.

An additional motivation to adopt this approach is the likely presence of transaction costs in trade between countries and their consequences for the long run PPP hypothesis (OBSTFELD; TAYLOR, 1997; JUVENAL; TAYLOR, 2008). The existence of transaction costs implies that adjustment will occur only once deviations are higher than the transaction costs (e.g., the threshold value), and hence the adjustment should not happen instantaneously and at each time.

Obstfeld and Taylor (1997) observed that in some countries, the transaction costs, transport, tariff and nontariff barriers prevent complete arbitrage transaction price in the international market for goods and services (law of one price) to certain ranges of values of the real exchange rate. In other words, the price differential would persist for certain values since the marginal cost of arbitration would be greater than the profit obtained by an economic agent, in the view of transaction costs.

In this context, it could be experiencing a "band of inaction" (no-arbitrage) to the price differential between the countries, which helps explain why the real exchange rate is not located on the long run exactly on the unit, i.e., the value of threshold parameters directly reflect the transaction costs in the economy.

The intuition behind the threshold model is that the arbitrage transactions would take place only after these parameters (thresholds) have been exceeded turning the operation profitable for the economic agent. Yet, in other countries there would be only two regime processes reflecting the iteration between pools of optimizing agents in the goods market (only one threshold) ${ }^{4}$ As example, consider

4 See Scheinkman (1990) for a number of examples of models in which the iteration between 
the case where a symmetric target for only one threshold, since macroeconomic policies are often organized around targets, where the intervention is activated only once the deviations from the target are significant.

The most trivial example is monetary policy during the Bretton Woods agreement where the exchange rate were pegged and allowed varies with only $+/-1 \%$ band. It may be interpreted as the existence of an explicit high and low level of exchange rate regimes. In case of without assumption of symmetry, other example of the two regimes (low and high) inflation was studied by Marques (2013), in which an estimated threshold of $5.14 \%$ of inflation per month separates the low and hyperinflation processes in Brazil.

Obstfeld and Taylor (1997) presented a seminal study employing the developments in the field of nonlinear time series based on works of Tong and Lim (1980) and Tong (1990) by assuming exogenously three regimes operating in all cases. The possibility of a nonlinear behavior for the real exchange rate may help explain why the deviations from parity are continuously non-uniform. Additionally, these deviations can be asymmetric over the business cycle and their behavior can also explain why the speed of adjustment tends to be as higher as greater the deviation around the parity. More importantly this approach may be possible to verify not only stationarity (necessary condition) but also the value for which the real exchange rate would converge in the long run (sufficient condition) with reasonable adjustment speed (OBSTFELD; TAYLOR, 1997).

A remarkable contribution was presented by Obstfeld and Taylor (1997) but their study presents some empirical limitations. Namely:

a) determining exogenous (arbitrary) number of regimes;

b) to impose (arbitrary) symmetry to the value of the thresholds;

c) to determining exogenous (arbitrary) the number of lags of the each state and transition variable and;

d) absence of stability analysis (convergence/stationary).

In this context, the aim of this study is to search for possible nonlinearities in the real exchange rate verifying whether the real exchange rate equilibrium converges to values close to unity (sufficient condition for the validity of PPP) and its stationarity property for a sample of twenty countries. Concretely, this study addresses the following aspects by applying the model Setar (TONG, 1990):

a) to determine the number of regimes necessary to describe the behavior of the real exchange rate;

b) relax the assumption of symmetry of thresholds;

c) to determine the best lag for each regime and the threshold parameter through an information criterion;

d) to verify the persistence of the regimes, and especially;

optimizing agents may generate nonlinearities, like limit cycles and chaotic trajectories. 
e) to verify the hypothesis of absolute PPP applying a procedure to investigate simultaneously the necessary and sufficient condition to validate the PPP (convergence to values close to unity).

The main contribution of the paper is to attend the question raised by Taylor and Taylor (2004) point out before by estimating the value of real exchange rate equilibrium (sufficient condition for PPP) for a number of countries where the nonlinearity of threshold type predominates, beyond the necessary condition of stationarity emphasized by unit root tests.

Other approaches have been designed to estimate the equilibrium value of real exchange rate for a number of countries by considering the macro fundamentals of the economy. One representative example is the estimates of fundamental equilibrium exchange rates (Feers) proposed by Cline and Williamson (2011) at Peterson Institute for International Economics ${ }^{5}$ and the International Monetary Fund estimates (IMF, 2013). The main difference between the method proposed here and the works cited above relies on the conditionality of macro fundamentals and the objective of the study, since that approaches listed above does not seek to test PPP hypothesis neither its nonlinearities or evaluate stationary property of real exchange rate.

This paper has been divided into four sections. The first section presents the problem, its significance and the main hypothesis of this study. Section two presents the methodology and theoretical model. The third section presents the results and discussions. Finally, the last section summarizes the main outcomes of this study.

\section{The Law of One Price and Purchasing Power Parity}

The law of one price is the base on which rests the hypothesis of purchasing power parity. For the case of internationally tradable goods, the law of one price, the absolute version, can be written as:

$$
P_{i, t}^{*}=E_{i} \cdot P_{i, t}, \quad i=1,2, \ldots, N
$$

Where $P_{i, l}$ denotes the price of the commodity $i$ in the domestic currency in period t. $P_{i, t}^{*}$ denotes the price of commodities in foreign currency $i$ at time $t$, and $E_{t}$ is the nominal exchange rate (ratio of foreign currency and domestic currency). The right hand side of the equation 1 expresses the value of the commodity $i$ sold in the domestic country in foreign currency. In most empirical studies, $P_{i, t}$ and $P_{i, t}^{*}$ are replaced by aggregated price indices of commodities and services. In turn, the real exchange rate to the British Standard is defined as:

$5 \quad$ For details of the model used see Cline (2008). 


$$
Q_{t}=E_{t} \cdot \frac{P_{t}}{P_{t}^{*}}
$$

Where $P_{t}^{*}$ and $P_{t}$ are aggregated price indices. If equation 1 is true, considering equation 2 , which expresses the trajectory of competitiveness of commodities and services among countries, $Q_{t}$ should converge to unity, since $E_{t} \cdot P_{t}$ and $P_{t}^{*}$ have their differential reduced to zero in view of arbitrage operations in market.

In the case of price differentials between countries, the agents can profit by buying at low prices and selling at higher prices internationally. Traditionally, it is assumed that the divergence of parity can be explained by transaction costs and trade barriers between countries. Consequently, the PPP hypothesis does not find support for a range of values of the real exchange rate, i.e., the agents have higher marginal costs than the marginal benefits ("band inaction").

However, exceeded the threshold value, interpreted as a sign of transaction costs, the benefits outweigh the costs and the agents operate in this market leading the real exchange rate to converge to its equilibrium value.

The hypothesis of purchasing power parity, in its absolute version, postulates that $Q_{t}$ should converge to unity in the long run, as the transactions of purchase and sale of commodities and services tend to validate equation $1 .^{6}$ Taking the logarithm of equation 2 yields:

$$
q_{t}=e_{t}+p_{t}-p_{t}^{*}
$$

Where $q_{t}$ would have mean and constant variance over time (stationary feature). This property ensures that after a shock, the real exchange rate converges to any constant in the long run. This is a necessary but not sufficient condition to validate the PPP theory, since the theoretical proposition is about the value of the variable $Q_{t}$ and not their mean reversion property.

As mentioned above, a large number of studies investigated the PPP hypothesis interpreting it as an equivalent to the property of mean reversion (necessary property) of the real exchange rate. In their studies, the majority of the authors used the traditional unit root tests with time series data, increasing its power by panel data analysis (TAYLOR, 2002). Details of this approach can be found in the works of Taylor and Taylor (2004), and especially in Lothian and Taylor (1997).

The perspective employed in this work part of the claim raised by Taylor and Taylor (2004) who observed that PPP theory is an assertion about the value of long run real exchange rate and not on its condition of stationarity, as has been

$6 \quad$ For a more detailed exposition of law of one price and the purchasing power parity, as a corollary, see Sarno and Taylor (2002). The authors also discuss in detail the definition and choice of variables to test correctly this hypothesis. In this paper we are following their approach. 
described in the literature. According to the authors it is necessary an effort to go beyond the stationarity tests and, in particular, to incorporate trade barriers and transaction costs in this analysis and to inform to which value the exchange rate may converge in the long run.

Following the approach of Obstfeld and Taylor (1997) and Juvenal and Taylor (2008), the methodology tests the hypothesis of linearity and also the number of regimes (thresholds) required to describe the behavior of the real exchange rate, absent in the previous works. In addition, a further step is provided at the end, as with the proposed method is possible to check the stationarity of exchange rate (necessary condition) and also to obtain the value for which it may converge in the long run (sufficient condition) to validate the PPP hypothesis. The central idea of this study is to answer "[...] the very long run of question: what is the equilibrium real exchange rate?" (TAYLOR; TAYLOR, 2004, p. 149).

\section{Methodology}

In this section, we describe the Hansen's test used to estimate the number of regimes, and we present the theoretical model designed to describe a number of regime changes. Besides, we describe the data used in the computations.

\subsection{Testing for Nonlinearity}

The evidence of a nonlinear behavior can be explored from some formal specific tests. Despite a large variety of developed tests in this area, this study follows the methodology of Hansen (1999). Traditional tools, such Tsay's (1986) test, can capture some types of nonlinearities in the time series behavior. However, it does not detect nonlinearity of the threshold type. Alternatively, the Hansen's (1999) test is able to detect the number of regimes (or thresholds) necessary to describe the nonlinear behavior of a time series, considering as null hypothesis the linear autoregressive model.

Based on bootstrap replications, the method of Hansen is computationally intensive. The null hypothesis assumes that the variable is described by an autoregressive model of order $p(A R(p))$, while the alternative hypothesis assumes that the data generating process follows a Setar model $(j)(j>k)$ with $m$ regimes $(m=$ $2,3)$. The statistic test is expressed by:

$$
F_{j k}=n\left(\frac{S_{j}-S_{k}}{S_{k}}\right)
$$

Where $S_{m}$ is the sum of squared residuals from the estimated models. Alike Chan's test, this test requires a minimum percentage of observations in each regi- 
me. In this work, the minimum was set at $15 \%$. In this context, it is important to note that Obstfeld and Taylor (1997) only assume the validity of the three regimes, based on this assumption, then, their model is estimated.

To Hansen (1999, p. 566), there are favorable arguments supporting the adoption of bootstrap method, which provides good approximation and it does not requires that the variable of interest to be stationary. Despite showing improvements over the existing empirical literature, the current study was unable to analyze the asymptotic behavior for the cases with linear dynamics.

\subsection{Theoretical Model for Regime Changes}

As specified by Bec, Salem and Carrasco (2004), the theoretical model for the case of three regimes can be expressed as:

$$
y_{t}=\left\{\begin{array}{lll}
\mu_{L}+\phi_{L, 1} y_{t-1}+\ldots+\phi_{L, p L} y_{t-p L}+\varepsilon_{t} & \text { if } & y_{t-d}<r_{1} \\
\mu_{M}+\phi_{M, 1} y_{t-1}+\ldots+\phi_{M, p M} y_{t-p M}+\varepsilon_{t} & \text { if } & r_{1} \leq y_{t-d} \leq r_{2}(5) \\
\mu_{H}+\phi_{H, 1} y_{t-1}+\ldots+\phi_{H, p H} y_{t-p H}+\varepsilon_{t} & \text { if } & y_{t-d}>r_{2}
\end{array}\right.
$$

where $\mu_{L}, \mu_{M}$, and $\mu_{H}$ are the intercepts in each regime; $p_{L}, p_{M}, p_{H}$ are the number of lags in each regime; $r_{1}$ and $r_{2}$ are the thresholds; $d$ is the delay parameter of transition variable; $y_{t-d}$ is the transition variable; and $\phi_{L, p L}, \phi_{M, p M}, \phi_{H, p H}$ are autoregressive coefficients to be estimated. We assume that $\varepsilon_{t}$ is i.i.d. $N\left(0, \sigma^{2}\right)$. And, in case of the occurrence of only two regimes (only one threshold case), the above model can be simplified to:

$$
y_{t}=\left\{\begin{array}{lll}
\mu_{L}+\phi_{L, 1} y_{t-1}+\ldots+\phi_{L, p L} y_{t-p L}+\varepsilon_{t} & \text { if } & y_{t-d} \leq r_{1} \\
\mu_{H}+\phi_{H, 1} y_{t-1}+\ldots+\phi_{H, p H} y_{t-p H}+\varepsilon_{t} & \text { if } & y_{t-d}>r_{1}
\end{array}\right.
$$

The intuition behind the Setar model, according to equation 6 for example, is that there are two linear submodels (regimes) and the mechanism described by it dictates which of them is operational in time, depending on the threshold position.

The threshold variable is a certain lagged value of the real effective exchange rate itself. Thus, for example, when $d=1$ the lag 1 value of the dependent variable is no greater than the threshold, the process is well described by the first linear submodel (the low regime is operational); otherwise, the behavior of the dependent variable is well described by the second submodel (the high regime is operational).

The estimation process is done by minimizing the sum of squared residuals (SSR). The minimization of the SSR is done through a grid search and the Mini- 
mum Akaike Information Criterion is computed each time: the value of the dependent is sorted, a certain percentage of the first and last values are excluded to guarantee a minimal number of observations in each regime. For large samples, and based on asymptotic arguments, Hansen (1999) and Cryer and Chan (2008) suggested a minimum of $10 \%$ percentage points. However, for small samples, as is the case of this study, we adopt a minimum of $15 \%$ percentage points to guarantee a minimum about of 60 observations in each regime.

The procedure to the two threshold case is the same one and it searches for all combinations of parameters to minimize the AIC criterion. For the two thresholds the computational burden is higher and may rapidly become cumbersome. The properties of this estimator can be found in Chan (1993). The values of $p$ maximum and $d$ maximum are somewhat arbitrary. To obtain greater flexibility, this implies we need to fix reasonable values of $d$ and $p$ which are higher than the conventional one, but no too large. Otherwise, the search algorithm may degenerate and the estimates may be subject of multicolinearity problem. Our baseline is the work of Obstfeld and Taylor (1997), in which those authors determine exogenously and the values of $d$ and $p$ are not allowed to vary accordingly (the authors fix $d=p=1$ for all estimates of their study).

In this respect, we follow the suggestion of Cryer and Chan (2008) and allowed $d$ and $p$ vary $(1 \leq d \leq 5$ and $1 \leq p \leq 3)$ and let the minimum AIC criterion to define the best fitting and parameters combination. Thus, with this less restrict approach we hope our model fitting will be better adjusted, but we fix low values for the maximum $p$ and $d$ to pay attention to computational burden as well. To see other alternatives ways to define the maximum $p$ and $d$, see the examples described in Cryer and Chan (2008).

\subsection{Data}

The dataset used in the study accounts for the availability of monthly data for the period post-1973, bearing in mind the search for a measure of the exchange rate that would accurately reflect the competitiveness between countries. Overall, the majority of studies use real exchange rate without considering the weight of trade between countries. However, there is well documented evidence which concludes that the trade balance strongly influences the behavior of the real exchange rate (HELMERS, 1991; OKIMOTO; SHIMOTSU, 2010). In a related study, Cline and Williamson (2011, p. 2) assert:

The relevant exchange rate concept is an effective rate, i.e., one which in foreign currencies are taken to account and weighted by their importance in the foreign trade of the country in question to form a single estimate of the exchange rate. The practice of measuring a currency's value in terms of the currency of single trading partner and calling this 'the exchange rate' is quite wrong for any country with reasonably diversified trade. 
Thus, the variable selected was the real effective exchange rate based on consumer price index for each individual country from a CD-ROM of the International Monetary Fund (IMF, 2012). This real effective exchange rate is based on a basket of 26 countries and euro as group. These 26 advanced economies include Austria, Belgium, Finland, France, Germany, Greece, Ireland, Italy, Luxembourg, Netherlands, Portugal, Spain, Australia, Canada, Denmark, Hong Kong SAR, Israel, Japan, Korea, New Zealand, Norway, Singapore, Sweden, Switzerland, United Kingdom, and United States.

The overall database for this variable computed by the IMF contain 30 countries, however, there are 10 countries with missing information in several years. Beyond those countries listed in the Table 1 with complete information, the following countries have missing information, and then they were excluded: Canada, Cyprus, Germany, Greece, Ireland, Italy, Netherlands, Portugal, Slovak Republic, and Japan. ${ }^{7}$

Table 1 - Countries sampled

\begin{tabular}{|c|c|c|c|c|c|}
\hline Country/sample & Variable & $\mathbf{N}$ & Country/sample & Variable & $\mathbf{N}$ \\
\hline 1. Austria/1975:01-2011:11 & $Y_{t}^{A U}$ & 443 & $\begin{array}{l}11 . \\
\text { Spain/1980:01-2011:11 }\end{array}$ & $Y_{t}^{S P}$ & 383 \\
\hline 2. Belgium/1984:01-2011:11 & $Y_{t}^{B E}$ & 443 & 12. Brazil/1979:12-2011:11 & $Y_{t}^{B R}$ & 384 \\
\hline 3. Finland/1975:01-2011:11 & $Y_{t}^{F I}$ & 443 & 13. Chile/1979:12-2011:11 & $Y_{t}^{\text {Chile }}$ & 384 \\
\hline 4. France/1979:12-2011:11 & $Y_{t}^{F R}$ & 384 & 14. Israel/1975:01-2011:11 & $Y_{t}^{I S}$ & 443 \\
\hline 5. Malaysia/1975:01-2011:11 & $Y_{t}^{G E}$ & 443 & $\begin{array}{l}\text { 15. Mexi- } \\
\text { co/1979:12-2011:11 }\end{array}$ & $Y_{t}^{M E}$ & 384 \\
\hline 6. Denmark/1975:01-2011:11 & $Y_{t}^{D E}$ & 443 & $\begin{array}{l}\text { 16. Switzer- } \\
\text { land/1975:01-2011:11 }\end{array}$ & $Y_{t}^{S W I}$ & 443 \\
\hline 7. Sweden/1975:01-2011:11 & $Y_{t}^{S W E}$ & 443 & $\begin{array}{l}\text { 17. Nor- } \\
\text { way/1975:01-2011:11 }\end{array}$ & $Y_{t}^{N O}$ & 443 \\
\hline $\begin{array}{l}\text { 8. New Zea- } \\
\text { land/1975:02-2011:11 }\end{array}$ & $Y_{t}^{N Z}$ & 442 & $\begin{array}{l}\text { 18. United } \\
\text { States/1979:12-2011:11 }\end{array}$ & $Y_{t}^{U S}$ & 384 \\
\hline $\begin{array}{l}\text { 9. Luxem- } \\
\text { bourg/1975:02-2011:11 }\end{array}$ & $Y_{t}^{L U}$ & 442 & $\begin{array}{l}\text { 19. United King- } \\
\text { dom/1975:02-2011:11 }\end{array}$ & $Y_{t}^{U K}$ & 442 \\
\hline 10. China/1979:12-2011:11 & $Y_{t}^{\text {China }}$ & 384 & $\begin{array}{l}\text { 20. Hunga- } \\
\text { ry/1979:12-2011:11 }\end{array}$ & $Y_{t}^{H U}$ & 384 \\
\hline
\end{tabular}

Source: IMF (2012).

7 The dataset is available upon request and with the journal's editor. 
The total trade weights used by the IMF to construct the nominal and the associated real effective exchange rates are designed to make them relevant to reflect the movement in costs and prices affecting imports and exports of manufactured goods. The weights are built up from aggregated trade flows for manufactured goods averaged over the period 2004-2006 taking into account the relative importance of a country's trading partners in its direct bilateral relations with them, in both the home and foreign markets; of the competitive relations with third countries in particular markets; and of the differences among countries in the importance of foreign trade to the manufacturing sector.

The Table 1 presents the sample used in the study, identifying the time window for each country and the sample period. Using this more accurate measure of the real exchange rate it is expected that the results will be more favorable to the PPP hypothesis. ${ }^{8}$

A visual inspection of Figure 1 (see Appendix A) allows some comments. Although some countries present marked tendency to decrease its competitiveness (appreciation) over the years, such as Denmark, Luxembourg, Austria, Hungary, Spain and Brazil, another group of countries present marked tendency to increase its competitiveness, with an apparent trend of currency depreciation, e.g., United States, China, Sweden and Malaysia. The other group of countries seems to experience moments of appreciation intercalated with moments of depreciation, without a clear trend. Additionally, in this group, the volatility of the exchange rate may well have been greater than in other cases.

Besides a marked tendency to increase or decrease their competitiveness, visual inspection suggests that in the cases of Mexico, Switzerland, Brazil and the United Kingdom emerge an apparent asymmetry in the behavior of the series, in which the ascending phase (appreciation) of the real exchange rate is markedly more gradual than the downward phase (depreciation). While currency appreciation tends to be gradual, the exchange rate depreciation seems to occur abruptly in time. Formal tests below may indicate more accurately whether assumption of linearity is reasonable to describe the data generating process of these countries.

\section{Results}

The results of the tests for specific (threshold) nonlinearities are presented in Tables 2. As explained previously, the strategy to test for the number of regimes (or thresholds) as the following. To test a SETAR (j) against SETAR $(k)(k>j)$ where $k$

8 Note that to interpret the path of the real exchange rate is necessary to consider that, according to equation 1, the real exchange rate "appreciated" means a "higher" rate, where many units of foreign currency are needed to buy one unit of domestic currency (trajectory ascending). An exchange rate "depreciated" means a "lower" rate of exchange, in which a few units of the foreign currency purchase many units of domestic currency (downward trend). 
and $j$ are the number of regimes we calculate the statistic defined in equation 4 , and, thus we use the conventional $F$ distribution to test the null against the alternative.

Table 2 - Hansen's test

\begin{tabular}{|c|c|c|c|c|}
\hline Country & $\begin{array}{l}\mathrm{H}_{0}: \operatorname{AR}(\mathrm{p}) \\
\mathrm{H}_{1}: \operatorname{SETAR}(2)\end{array}$ & $\begin{array}{l}\mathrm{H}_{0}: \operatorname{AR}(p) \\
\mathrm{H}_{1}: \operatorname{SETAR}(3)\end{array}$ & $\begin{array}{l}\mathbf{H}_{0}: \operatorname{SETAR}(2) \\
\mathrm{H}_{1}: \operatorname{SETAR}(3)\end{array}$ & Regimes \\
\hline 1. Austria & $\begin{array}{l}24.3383 \\
(0.2533) \\
\end{array}$ & $\begin{array}{l}41.2058 \\
(0.6167) \\
\end{array}$ & $\begin{array}{l}15.9680 \\
(0.8467) \\
\end{array}$ & ----- \\
\hline 2. Belgium & $\begin{array}{l}28.1625 \\
(0.1933)\end{array}$ & $\begin{array}{l}16.1136 \\
(0.9967)\end{array}$ & $\begin{array}{l}-11.3115 \\
(1.000)\end{array}$ & ------ \\
\hline 3. Finland & $\begin{array}{l}55.7244^{\text {**** }} \\
(0.0033) \\
\end{array}$ & $\begin{array}{l}77.8724^{\text {*** }} \\
(0.0167) \\
\end{array}$ & $\begin{array}{l}19.6175 \\
(0.6933) \\
\end{array}$ & 2 \\
\hline 4. France & $\begin{array}{l}65.2308^{\text {k.ktkt }} \\
(0.0000)\end{array}$ & $\begin{array}{l}100.2683^{\text {what }} \\
(0.0000)\end{array}$ & $\begin{array}{l}29.8222^{*} \\
(0.0967)\end{array}$ & 3 \\
\hline 5. Malaysia & $\begin{array}{l}67.8172^{* *} \\
(0.0167)\end{array}$ & $\begin{array}{l}109.9351^{* * *} \\
(0.0133)\end{array}$ & $\begin{array}{l}36.4032 \\
(0.1400)\end{array}$ & 2 \\
\hline 6. Denmark & $\begin{array}{l}18.2924 \\
(0.6533) \\
\end{array}$ & $\begin{array}{l}54.3529 \\
(0.1500) \\
\end{array}$ & $\begin{array}{l}34.5956 \\
(0.0700) \\
\end{array}$ & ----- \\
\hline 7. Sweden & $\begin{array}{l}22.9842 \\
(0.4133) \\
\end{array}$ & $\begin{array}{l}43.9518 \\
(0.5067) \\
\end{array}$ & $\begin{array}{l}19.9084 \\
(0.6000) \\
\end{array}$ & ---- \\
\hline 8. New Zealand & $\begin{array}{l}27.3413 \\
(0.1500)\end{array}$ & $\begin{array}{l}53.5493 \\
(0.1533)\end{array}$ & $\begin{array}{l}24.6445 \\
(0.2800)\end{array}$ & ---- \\
\hline 9. Luxembourg & $\begin{array}{l}31.5895 \\
(0.1133) \\
\end{array}$ & $\begin{array}{l}63.9010 \\
(0.1700) \\
\end{array}$ & $\begin{array}{l}30.1050 \\
(0.3267) \\
\end{array}$ & ---- \\
\hline 10. China & $\begin{array}{l}76.0932^{* * * *} \\
(0.0033)\end{array}$ & $\begin{array}{l}103.0977^{\text {*** }} \\
(0.0500)\end{array}$ & $\begin{array}{l}22.4290 \\
(0.4633)\end{array}$ & 2 \\
\hline 11. Spain & $\begin{array}{l}32.9247^{*} \\
(0.0867)\end{array}$ & $\begin{array}{l}61.3935^{*} \\
(0.0733) \\
\end{array}$ & $\begin{array}{l}26.1540 \\
(0.3267) \\
\end{array}$ & 2 \\
\hline 12. Brazil & $\begin{array}{l}89.6688^{\text {**** }} \\
(0.0000)\end{array}$ & $\begin{array}{l}139.5684^{\text {**** }} \\
(0.0000)\end{array}$ & $\begin{array}{l}40.2287^{* * *} \\
(0.0167)\end{array}$ & 3 \\
\hline 13. Chile & $\begin{array}{l}40.5367^{* * *} \\
(0.0233)\end{array}$ & $\begin{array}{l}64.9081^{*} \\
(0.0533)\end{array}$ & $\begin{array}{l}21.9824 \\
(0.4433)\end{array}$ & 2 \\
\hline 14. Israel & $\begin{array}{l}82.9072^{\text {k*t*k}} \\
(0.0067) \\
\end{array}$ & \begin{tabular}{|l}
$123.1568^{\text {kn*kt }}$ \\
$(0.0100)$ \\
\end{tabular} & $\begin{array}{l}33.7688 \\
(0.1567) \\
\end{array}$ & 2 \\
\hline 15. Mexico & \begin{tabular}{|l}
$119.8482^{\text {knkth }}$ \\
$(0.0000)$ \\
\end{tabular} & \begin{tabular}{|l|}
$201.0067^{\text {nk*kt}}$ \\
$(0.0000)$ \\
\end{tabular} & $\begin{array}{l}61.4228^{* * * *} \\
(0.0000) \\
\end{array}$ & 3 \\
\hline 16. Switzerland & $\begin{array}{l}67.3211^{\text {**** }} \\
(0.0000) \\
\end{array}$ & $\begin{array}{l}95.2852^{\text {**** }} \\
(0.0000) \\
\end{array}$ & \begin{tabular}{|l|}
24.1939 \\
$(0.3767)$ \\
\end{tabular} & 2 \\
\hline 17. Norway & $\begin{array}{l}48.0925^{\text {w.*t }} \\
(0.0067)\end{array}$ & $\begin{array}{l}84.5210^{\text {w*** }} \\
(0.0033)\end{array}$ & $\begin{array}{l}32.7792 \\
(0.1267)\end{array}$ & 2 \\
\hline
\end{tabular}


conclusão.

\begin{tabular}{|c|c|c|c|c|}
\hline Country & $\begin{array}{l}\mathrm{H}_{\mathrm{o}}: \operatorname{AR}(\mathrm{p}) \\
\mathrm{H}_{1}: \operatorname{SETAR}(2)\end{array}$ & $\begin{array}{l}H_{0}: \operatorname{AR}(p) \\
H_{1}: \operatorname{SETAR}(3)\end{array}$ & $\begin{array}{l}\mathrm{H}_{\mathrm{o}}: \operatorname{SETAR}(2) \\
\mathrm{H}_{\mathrm{i}}: \operatorname{SETAR}(3)\end{array}$ & Regimes \\
\hline 18. United States & $\begin{array}{l}30.1626 \\
(0.1033)\end{array}$ & $\begin{array}{l}56.2777 \\
(0.0867)\end{array}$ & $\begin{array}{l}24.1614 \\
(0.3067)\end{array}$ & ------- \\
\hline 19. United Kingdom & $\begin{array}{l}33.9413^{\text {k* }} \\
(0.0200) \\
\end{array}$ & $\begin{array}{l}62.9186^{\text {*** }} \\
(0.0333) \\
\end{array}$ & $\begin{array}{l}26.8619 \\
(0.2133) \\
\end{array}$ & 2 \\
\hline 20. Hungary & $\begin{array}{l}43.5997^{\text {***** }} \\
(0.0033)\end{array}$ & $\begin{array}{l}71.1287^{* *} \\
(0.0167)\end{array}$ & $\begin{array}{l}24.6480 \\
(0.3533)\end{array}$ & 2 \\
\hline
\end{tabular}

Source: Author's elaboration.

Note: The maximum number of lags (AR parameters) allowed in the estimations to produce white noise residuals, following Hansen (1999), was set at 11 . The p-values of the estimates are into brackets. Were adopted 300 bootstrap replications. *** Statistically significant at $P$ $=0.01$ level; * ${ }^{*}$ statistically significant at $P=0.05$ level; * statistically significant at $P=0.10$ level. To choose the significance level, the researcher may follow the suggestion raised by Wooldridge (2003, p. 134-136).

For example, in case of Austria, the result shown in the second column of the Table 2 indicates that there is no evidence (at $5 \%$ of significance) to reject the linear $\operatorname{AR}(p)$ model against SETAR $(m)$ as the alternative, where $m$ is the number of regimes $(m=1,2,3)$. The same conclusion is valid for the third column. In this case, the linear $\operatorname{AR}(p)$ well describe the data of the this country better than a SETAR $(m)$ model.

However, in case of France the result presented in the second column indicates that there is evidence (at $5 \%$ of significance) to reject the null of linear $\operatorname{AR}(p)$ model against SETAR(2). The same conclusion follows if we observe the third column for this country. A step further is needed, then we test the SETAR(2) as the null against SETAR(3) as the alternative hypothesis. In this country, if we consider a less restrictive degree of significance (at 10\% significance), there is enough evidence to reject the null of two in favor of a SETAR with 3 regimes to describe the data of this country. As the p-value shown into brackets is the level of credibility of the null, we have enough evidence to reject it with high degree of probability (0.9033). The same sequence of hypothesis testing was made for all countries of the study.

Thus, the results in Table 2 suggest that in the 13 of the 20 countries $(65 \%$ of the sample) the assumption of linearity is rejected in favor of nonlinearity of the threshold type. Among these 13 countries, 10 are subject to regime change with only one threshold and 3 countries are subject to regime change with two thresholds.

Therefore, for this group of 13 countries with a focus on nonlinearity and better accuracy when compared to previous studies will be possible to test the hypothesis of purchasing power parity in its absolute version. Additionally, to answer the double question posed in this work, i.e., whether the real exchange rate of that 
economy is stationary (converges or has cyclical behavior around a mean), and if so, whether this value would be close to unity in the long run.

Knowing the number of regimes necessary to describe the behavior of the real exchange rate of the 13 countries subject to regime switching, the next step consisted in selecting the best model. Specifically, the search algorithm for the best model requires the definition of the number of thresholds determined previously by the Hansen test, setting the maximum lag allowed in each regime $(0 \leq p L, p M, p H \leq 3)$, setting the maximum lag for the threshold parameter $(1 \leq d \leq 5)$, setting the minimum percentage of observations each regime (set at $15 \%$ ) and finally the definition of a criterion of information. For all these choice criteria we are following the arguments raised by Cryer and Chan (2008). In this case we used the traditional Akaike Information Criterion (AIC).The estimation results are displayed in Table 3.

Table 3 - Estimates by country

\begin{tabular}{|c|c|c|}
\hline Country & \multicolumn{2}{|l|}{ Best model } \\
\hline \multicolumn{3}{|c|}{ Two regimes } \\
\hline 1. Finland & $\begin{array}{l}y_{t}^{F I}=\left\{\begin{array}{lc}8.096180+0.926196 y_{t-1} \\
(0.1526) & (0.0000) \\
-3.399416+1.017092 y_{t-1} & \text { if } \\
(0.4884) & (0.0000)\end{array} \text { if }\right. \\
\text { L: } 59.16 \% ; \mathrm{H}: 40.84 \% \sigma_{\varepsilon}^{2}=18.83 \mathrm{AIC}=1310\end{array}$ & $\begin{array}{l}y_{t-5} \leq 111.60 \\
y_{t-5}>111.60\end{array}$ \\
\hline 2. Malaysia & $\begin{array}{l}y_{t}^{M A}=\left\{\begin{array}{lr}6.334735+0.944879 y_{t-1} \\
(0.1211) & (0.0000) \\
2.412601+0.971949 y_{t-1} & \text { if } \\
(0.6801) & (0.0000)\end{array} \text { if }\right. \\
\text { L: 63.66\%; H: } 21.45 \% \sigma_{\varepsilon}^{2}=69.02 \mathrm{AIC}=1886\end{array}$ & $\begin{array}{l}y_{t-4} \leq 139.00 \\
y_{t-4}>139.00\end{array}$ \\
\hline 3. China & $\begin{array}{l}y_{t}^{\text {China }}= \begin{cases}16.476829+0.853214 y_{t-1} & \text { if } \\
(0.0002767) & (0.0000) \\
-41.434317+1.094455 y_{t-1} & \text { if } \\
(0.0000) & (0.0000)\end{cases} \\
\text { L: } 78.55 \% \text { H: } 24.16 \% \hat{\sigma}_{\varepsilon}^{2}=104.9 \mathrm{AIC}=1797\end{array}$ & $\begin{array}{l}y_{t-4} \leq 161.20 \\
y_{t-4}>161.20\end{array}$ \\
\hline
\end{tabular}




\section{Two regimes}

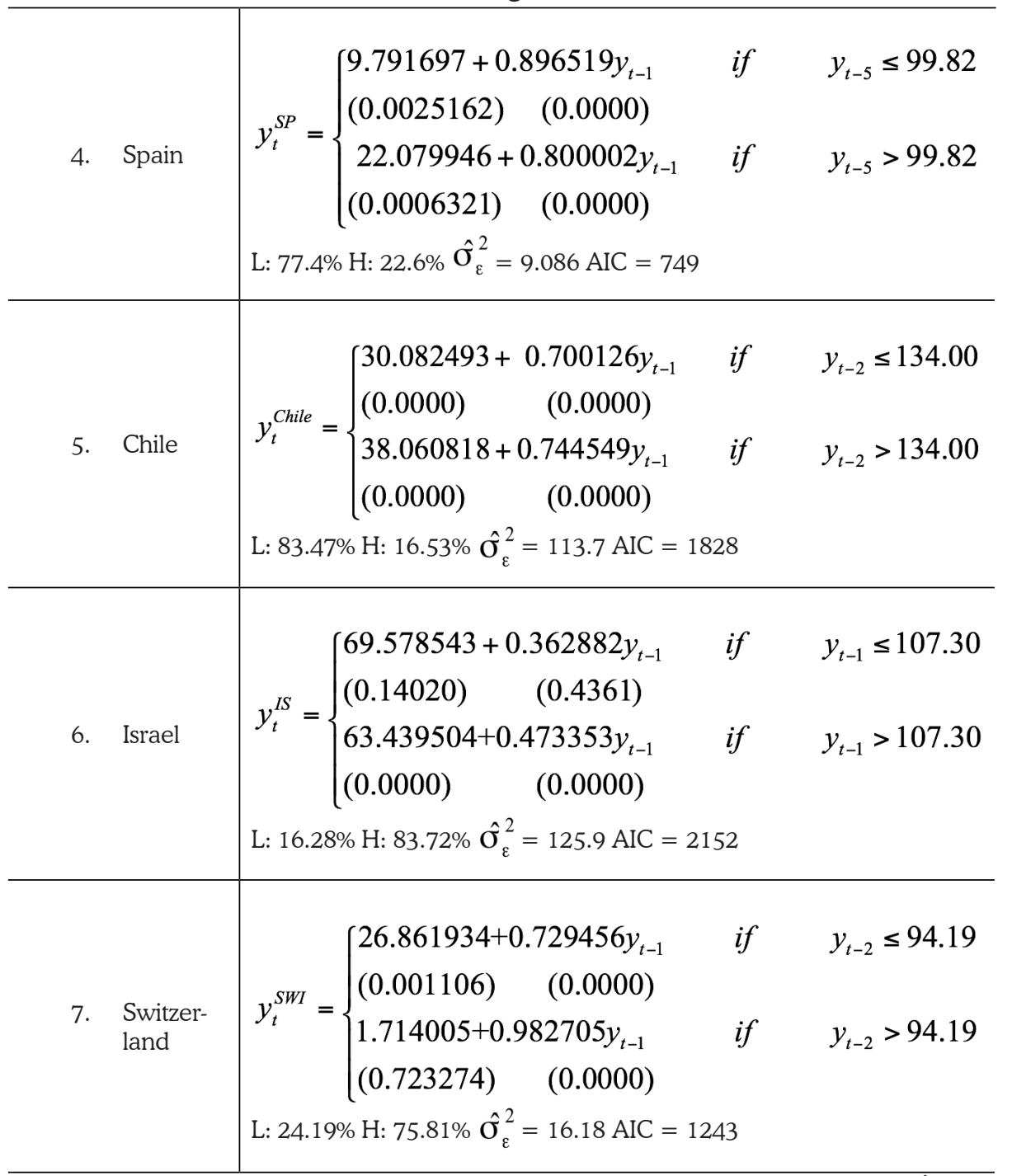


Two regimes

8. Norway $\quad y_{t}^{N O}=\left\{\begin{array}{lrl}22.276652+0.775509 y_{t-1} & \text { if } & y_{t-5} \leq 102.90 \\ (0.0000) & (0.0000) & \\ 76.380389+0.234244 y_{t-1} & \text { if } & y_{t-5}>102.90 \\ (0.0000) & (0.06764) & \end{array}\right.$

L: $86.77 \%$ H: $13.23 \% \hat{\sigma}_{\varepsilon}^{2}=9.994 \mathrm{AIC}=1030$

9. $\begin{array}{ll}\text { United } \\ \text { Kingdom }\end{array} y_{t}^{U K}=\left\{\begin{array}{lll}21.108927+0.766210 y_{t-1} & \text { if } & y_{t-1} \leq 83.48 \\ (0.06617) & (0.0000) & \\ 5.698243+0.926059 y_{t-1} & \text { if } & y_{t-1}>83.48 \\ (0.18529) & (0.0000) & \end{array}\right.$

L: $31.57 \% \mathrm{H}: 68.43 \% \hat{\sigma}_{\varepsilon}^{2}=24.86 \mathrm{AIC}=1430$

10. Hungary $y_{t}^{H U}=\left\{\begin{array}{lrl}-3.576565+1.069833 y_{t-1} & \text { if } & y_{t-4} \leq 97.71 \\ (0.003571) & (0.0000) \\ 85.751651+0.173372 y_{t-1} & \text { if } & y_{t-4}>97.71 \\ (0.0000) & (0.05713) & \end{array}\right.$

L: $82.57 \% \mathrm{H}: 17.43 \% \hat{\sigma}_{\varepsilon}^{2}=16.15 \mathrm{AIC}=1078$

\section{Three regimes}

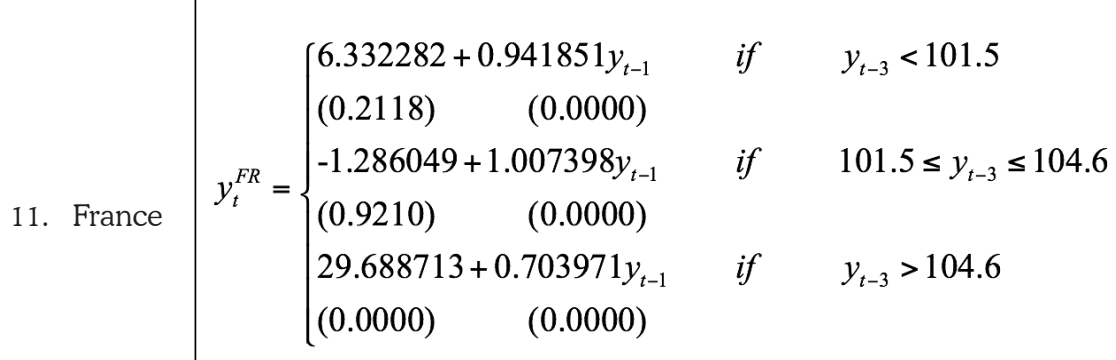

L: $52.41 \% \mathrm{M}: 21.39 \% \mathrm{H}: 26.2 \% \hat{\sigma}_{\varepsilon}^{2}=5.045 \mathrm{AIC}=637$

continua... 


\section{Two regimes}

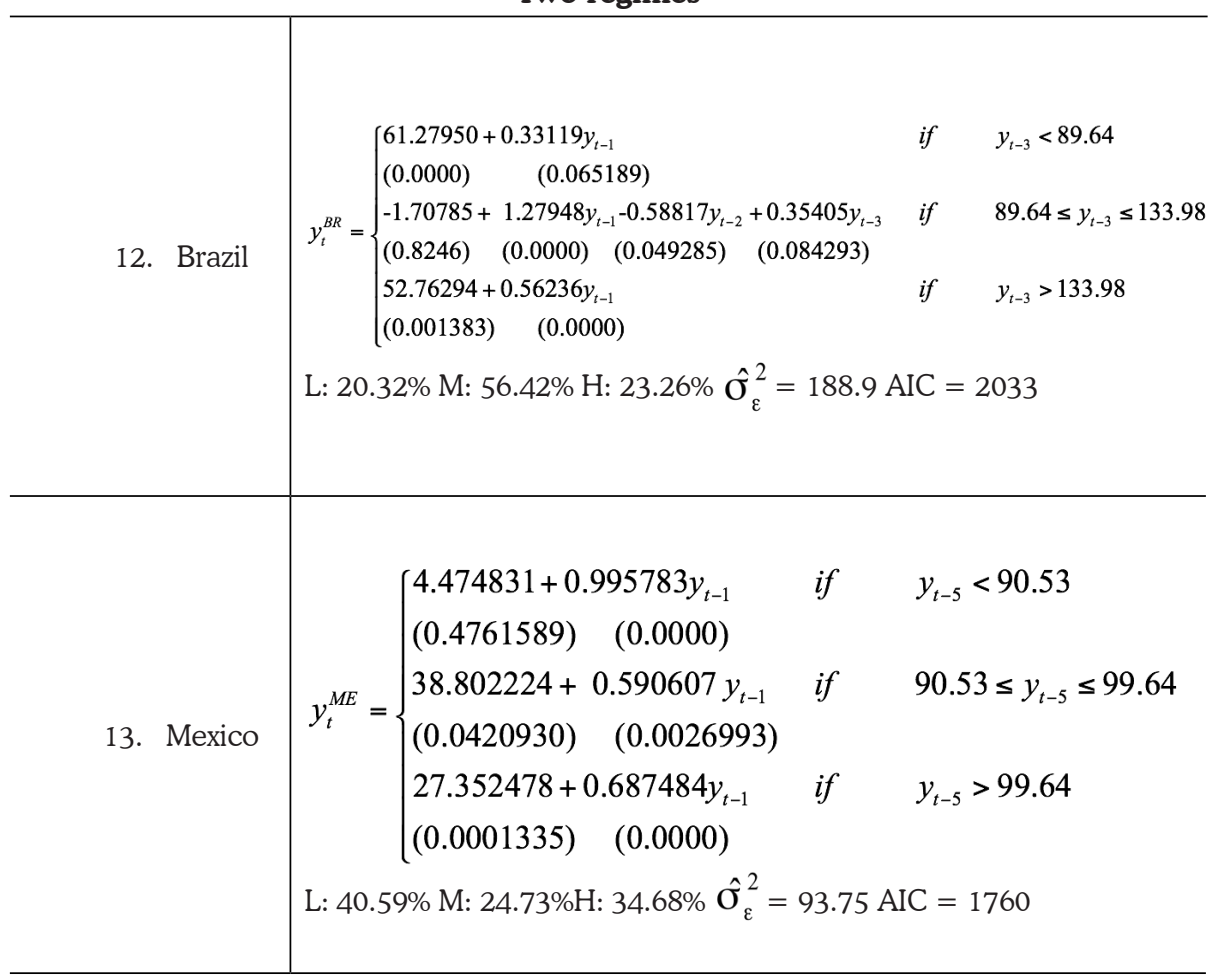

Source: Author's elaboration.

Note: The p-value of the estimates are into brackets. 
Table 3 summarizes the parameters of the equations 9 or 10 for the countries that have nonlinear dynamics (13 in total). Besides the constant and autoregressive coefficients estimated for all regimes $\left(u_{L} ; \mu_{M} ; \mu_{H} ; \phi_{L, 1}, \ldots, \phi_{L, p L} ; \phi_{M, 1}, \ldots, \phi_{M, p M} ; \phi_{H, 1}, \ldots, \phi_{H, p H}\right)$ are presented the values for transition variables $y_{t-d}$ and their lags, $d$. Moreover, are also presented information on the persistence of regimes $(L, M, H)^{9}$ and the variance of residuals $\left(\sigma_{\varepsilon}^{2}\right)$ together with the value of the information criterion (AIC) used to select the best model.

For instance, we observe that all the coefficients are significant at 0.01 probability for China. The high value of the transition variable (161.20) and high persistence of the system (0.7855) suggest that the China's regime of high competitiveness has high persistence because the number of observations below the threshold is high.

Finally, obtained the best model for the real exchange rate of each country, the next step was to examine the stationarity of the process calculating its equilibrium value in the long run. This analysis was performed after obtaining the skeleton of the estimated models. The skeleton of the Setar is obtained by suppressing the error term in each estimated equation and then through iterations performed from its deterministic version.

For any arbitrary initial value $\left(y_{0}\right)$, since all other magnitudes all known in each estimated model, when we fixed the error tem into zero, by iteration, all values of $y$ along $t$ periods may be traced back. All these values are shown in the Figure $2 .{ }^{10}$ It is demonstrated that for any initial value, if the skeleton converges to an equilibrium value (a constant or a closed path - limit cycle), indicating stationary, the stochastic model is also asymptotically stable (CHAN; TONG, 1985; CRYER; CHAN, 2008; TONG, 1990).

The skeleton time path can be better visualized graphically for each particular country. The hypothesis is that, in spite of large exchange rate depreciation, fixed around $20 \%$ in the short run, in the long run the real exchange rate equilibrium, for any initial value has a stable behavior indicating its stationarity. ${ }^{11}$ All trajectories of the equilibrium exchange rate exhibit stationary behavior converging to a constant, or alternatively, in some cases, have limit cycle behavior with ceiling and floor (closed path), independent of exogenous shock. That is, for any depreciation

9 The measure of persistence of each regime is given by the unconditional probability of occurrence of each regime, defined by: where $n$ is the sample size and is the effective sample size in the $i$-th regime.

10 See the examples given in Cryer and Chan (2008).

11 We assume the value of $20 \%$ depreciation based on the historical experience in a sample of 54 countries studied in Fratzscher (2009). The author concludes that, in average, the exchange rate of the sample countries depreciated $23 \%$ during the crisis against US dollar. For the Asian crisis in 1997, see Granger, Huang and Yang (2000, p. 342) in which the median of the exchange rate depreciation is $45.52 \%$. 
or appreciation, the exchange rate in the long run is the same. These behaviors can be seen in Figure 2 in the Appendix A.

To facilitate understanding, skeleton behaviors were summarized in Table 4, where countries were grouped by the number of regimes necessary to describe the trajectory of long run real exchange rate. Overall, the results suggest the stationarity of the real exchange rate (convergence to a constant or limit cycle).

Table 4 - Lon run behavior of the real exchange rate after $20 \%$ of devaluation

\begin{tabular}{l|l}
\multicolumn{1}{c|}{ Two regimes } & \multicolumn{1}{c}{ Long run behavior } \\
\hline Finland & Converges to 109.70 \\
\hline Malaysia & Converges to 114.92 \\
\hline China & Converges to 112.25 \\
\hline Spain & Converges to 94.62 \\
\hline Chile & Converges to 100.32 \\
\hline Israel & Converges to 120.46 \\
\hline Switzerland & Converges to 99.09 \\
\hline Norway & Converges to 99.23 \\
\hline United Kingdom & Limit cycle: maximum 84.96 and minimum 83.34 \\
\hline Hungary & Converges to 103.74 \\
\hline \multicolumn{1}{c}{ Three regimes } & \multicolumn{1}{c}{ Long run behavior } \\
\hline France & Limit cycle: maximum 102.68 and minimum 99.99 \\
\hline Brazil & Limit cycle: maximum 145.01 and minimum 123.01 \\
\hline Mexico & Converges to 94.78 \\
\hline
\end{tabular}

Source: Author's elaboration.

This table presents the main results achieved in the study, in particular, the values obtained for which the real effective exchange rate of countries can converge in the long run, i.e., its real exchange rate equilibrium. The results suggest that the hypothesis of PPP, in the absolute version, is supported by only five of the thirteen countries with nonlinear dynamics. In the cases of France, Norway, Switzerland, Chile and Hungary the behavior of the skeleton supports the PPP hypothesis because the exchange rate equilibrium of these countries is very close to unity.

Here, the criterion adopted to assert that this distance is small (or big) to corroborate the PPP hypothesis is only an economic one, since to the best of our knowledge there is no way to test the value obtained by the skeleton in relation to its expected theoretical value, since its asymptotic distribution is unknown.

Indeed, if we adopt the well knowledge Bretton Woods' criterion to activate monetary policy to maintain the level of exchange rate inside the band, the narrow rule of $+/-1 \%$ exchange rate deviation from unity lead to the conclusion that only 
in four countries absolute PPP is corroborated: Chile, Switzerland, Norway and France. ${ }^{12}$

However, in a context of floating exchange rate in which the central banks operates its policy by the interest rate, the broader criterion seems more reasonable. Thus, we suggest that the occurrence of $+/-5 \%$ exchange rate deviation from unity does not violate the PPP hypothesis; by adopting this economic interpretation the results indicate that Hungary should be included in the above group of countries.

In other cases, there are two groups of countries with the exchange rate equilibrium far from parity. Some of them have an exchange rate equilibrium appreciated (Brazil, Israel, China, Malaysia and Finland) and the other group (Spain, England and Mexico) presents an exchange rate equilibrium depreciated in the long run, far from the value postulated by absolute PPP. Accounting for it, would be interesting to compare these results with what is expected theoretically on the value of the real exchange rate equilibrium in these economies.

Williamson (2008) and Taylor and Taylor (2004) indicate that real exchange rate equilibrium of countries tends to be located at some value that may differ from parity, especially depending on the net international investment position and the countries' production structure. Therefore, it is expected theoretically that from a clash of debt to cover the interest on the debt, the real exchange rate equilibrium of an indebted country to be more competitive (depreciated) over the long run, aiming the reduction in external purchases and expansion of their exports.

Additionally, it is expected theoretically the opposite trend in countries that maintain a creditor's position in the international context, i.e., these countries should exhibit a less competitive appreciated real exchange rate. Lane and Milesi-Ferreti (2006) presented evidence that generally supports this assertion. ${ }^{13}$

These theoretical arguments may help explain the contrast between the results obtained in this study and the ones we observed in the trajectory of the skeletons estimated for each particular country.

The results presented in Table 4 suggest that Brazil, Israel, China, Malaysia and Finland would be creditors in the context of the world economy, because their real exchange rate equilibrium is appreciated in the long run. On the other hand, countries like Spain, England and Mexico would be debtors in this context because their real exchange rate equilibrium is depreciated over the long run.

$\overline{12}$ See Cohen (2017) for a description of how Bretton Woods' monetary policy worked in relation to exchange rate's band.

13 The Balassa-Samuelson effect, discussed in Taylor and Taylor (2004) and Balassa (1964), based on the configuration of the productive structure of the country is fully consistent with the hypothesis of external indebtedness discussed here. 
The current account surplus (percent of GDP) predicted by the International Monetary Fund (IMF, 2013) for China, Malaysia, Israel and Spain for the year 2018 is $4.3 \%, 4.5 \%, 2.3 \%$ and $3.6 \%$ respectively (IMF, 2013).

This forecast is consistent with the less competitive exchange rate regime that should prevail in these countries in the future (see Figures 1 and 2 in the Appendix A) since the balance of trade is directly correlated to the real exchange rate equilibrium.

According to the same document the forecast is a current account deficit of around 3.4\% for the year 2018 for the case of Brazil. This result indicates the need for a more detailed study for this case, as the results of this study suggest the occurrence of a significantly exchange rate appreciated in Brazil. However, with persistent deficits, a more competitive (depreciated) regime will be required to cover foreign commitments through trade surpluses.

The balance of current account (percent of GDP) deficit forecasted by IMF for England, Mexico and Finland is 2.6\%, 1.2\% and 1.8\%, respectively, for the year 2018. This prediction is consistent with the results presented in Table 4 since the occurrence of a current account deficit implies that the exchange rate equilibrium of these countries should be depreciated over the long run.

\section{Final Considerations}

The main objective of the study was to test the hypothesis of purchasing power parity in the absolute version with a nonlinear approach, consistent with the transaction costs. The methodology employed was based on the application of general and specific tests for nonlinearity for determining the number of regimes from data and search for the best model for each particular country. And finally, to identify the real exchange rate long run behavior.

This study contributes to existing knowledge of the exchange rate behavior by providing the following outcomes: a) it was possible to determine the number of regimes endogenously from the data; $b$ ) the best model was obtained without imposing symmetry to the value of the thresholds with search algorithm that minimizes the information criterion to determine endogenously the best lag in each regime for the autoregressive coefficients and the threshold parameter; c) through the skeleton of the fitted models was possible to determine the stationarity and the equilibrium value for the real exchange rate in the long run subject to regime change.

The results corroborate the hypothesis of absolute PPP in five sample countries: France, Norway, Switzerland, Chile and Hungary. In such cases, the equilibrium exchange rate is very close to unity as postulated theoretically by the PPP. 
Two other groups of countries emerge with exchange rate equilibrium away from parity.

Brazil, Israel, China, Malaysia and Finland can be considered probable creditors in the context of the world economy because its real exchange rate is appreciated in the long run. On the other hand, countries like Spain, England and Mexico can be considered probable debtors in the context of the world economy, because its real exchange rate would be depreciated over the long run.

\section{References}

BALASSA, B. The Purchasing power parity doctrine: a reappraisal. Journal of Political Economy, v. 72, p. 584-596, 1964.

BEC, F.; SALEM, M. B.; CARRASCO, M. Tests for unit-root versus threshold specification with an application to the purchasing power parity relationship. Journal of Business $\mathcal{E}$ Economic Statistics, v. 22, n. 4, p. 382-395, 2004.

BHAGWATI, J. Why are services cheaper in poor countries. Economic Journal, v. 94, p. 279286, 1984.

CERRATO, M.; HYUNSOK, K.; MACDONALD, R. Three-regime asymmetric STAR modeling and exchange rate reversion. Journal of Money, Credit, and Banking, v. 42, n. 7, p. 1447-1467, 2010.

CHAN, K. S. Consistency and limiting distribution of the least squares estimator of a threshold autoregressive model, The Annals of Statistics, vol, 21, n. 1, p. 520-533, 1993.

Percentage points of likelihood ratio tests for threshold autoregression. Journal of Royal Statistical Society, v. 53, n. 3, p. 691-696, 1991. 1990.

. Testing for threshold autoregression. The Annals of Statistics, v. 18, n. 4, p. 1886-1894,

CHAN, K. S.; TONG, H. On the use of the deterministic Lyapunov function for the ergodicity of stochastic difference equations. Advances in Applied Probability, v. 17, p. 666-678, 1985.

CLINE, W. R. Estimating consistent fundamental equilibrium exchange rates. Washington, DC, 2008. (Working Paper 08-6).

CLINE, W. R.; WILLIAMSON, J. Estimates of fundamental equilibrium exchange rates. Washington, DC, 2011. (Policy Brief n. PB 11-5). (Policy Brief n. PB 12-14).

COHEN, B. Bretton Woods system. Santa Barbara, CA, 2017. Available in: <http://www. polsci.ucsb.edu/faculty/cohen/recent/bretton.html >. Access in: Jan. 29th, 2017.

CRYER, J. D.; CHAN, K. S. Time series analysis. New York: Springer, 2008. 
DIVINO, J.; TELES, V.; ANDRADE, J. On the purchasing power parity for Latin-American countries. Journal of Applied Economics, v. 12, n. 1, p. 33-54, 2009.

DORNBUSCH, R. Expectations and exchange rate dynamics. Journal of Political Economy, v. 84, n. 6, p. 1161-1176, 1976.

. Open economy macroeconomics. New York: Basic Books, 1980.

ELLIOT, E.; KIEL, L. Introduction. In: (Ed.). Chaos theory in the social sciences: foundations and applications. Michigan: Michigan University Press, 2004. p. 1-15.

ELLIOT, G.; ROTHENBERG, T. J.; STOCK, J. H. Efficient tests for an autoregressive unit root. Econometrica, v. 64, n. 4, p. 813-836, 1996.

FRANSES, P.; VAN DIJK, D. Nonlinear time series models in empirical finance. Cambridge: Cambridge University Press, 2003.

FRATZSCHER, M. What explains global exchange rate movements during the financial crisis. Frankfurt , 2009. (Working Paper Series n. 1060).

GRANGER, C. W. J.; HUANG, B.-N.; YANG, C.-W. A bivariate causality between stock prices and exchange rates: evidence from recent Asian flu. Quarterly Review of Economics and Finance, v. 40, p. 337-354, 2000.

GRANGER, C. W. J; TERASVIRTA, T. Modelling nonlinear economic relationships. Oxford: Oxford University Press, 1993.

HAMILTON, J. A new approach to the economic analysis of nonstationary time series and business cycle. Econometrica, v. 57, n. 2, p. 357-384, 1989.

HANSEN, B. Testing for linearity. Journal of Economic Surveys, v. 13, n. 5, p. 551-576, 1999.

HELMERS, F. The real exchange rate. In: DORNBUSCH, R.; HELMERS, F. (Ed.). The open economy: tools for policymakers in developing countries. Oxford: Oxford University Press, 1991. p. 10-33.

INTERNATIONAL MONETARY FUND. International financial statistics. Washington, DC, 2012. 1 CD-ROM.

. World economic outlook, April 2013: hopes, realities, risks. Washington, DC, 2013.

JUVENAL, L.; TAYLOR, M. Threshold adjustment of deviations from the law of one price. Studies in Nonlinear Dynamics \& Econometrics, v. 12, n. 3, p. 1-44, 2008.

KAPETANIOS, G.; SHIN, Y. Unit root tests in three-regime SETAR models. Econometrics Journal, v. 9, n. 2, p. 252-278, 2006.

KIM, S.; LIMA, L. R. Local persistence and PPP the hypothesis. Journal of International Money and Finance, v. 29, p. 555-569, 2010.

KRUGMAN, P. Pricing to market when exchange rate changes. Cambridge, MA, 1986. (NBER Working Paper n. 1926). 
LANE, P.; MILESI-FERRETTI, G. The external wealth of nations mark II: revised and extended estimates of foreign assets and liabilities, 1970-2004. Washington, DC, 2006. (IMF Working Paper 06/69).

LOTHIAN, J.; TAYLOR, M. Real exchange rate behavior: the problem of power and sample size. Journal of International Money and Finance, v. 16, n. 6, p. 945-954, 1997.

MARQUES, A. M. Não linearidades, mudança de regime e assimetrias na inflação brasileira: análise a partir de um modelo Setar, 1944-2009. Economia e Sociedade, Campinas, v. 22, n. 1, p. 141-163, 2013.

OBSTFELD, M.; ROGOFF, K. Foundations of international macroeconomics. Cambridge, MA: MIT, 1996.

OBSTFELD, M.; TAYLOR, A. Nonlinear aspects of goods-market arbitrage and adjustment: Heckscher's commodity points revisited. Journal of the Japanese and International Economies, v. 11, p. 441-479, 1997.

OKIMOTO, T.; SHIMOTSU, K. Decline in the persistence of real exchange rates, but not sufficient for purchasing power parity, Journal of The Japanese and International Economies, v. 24, p. 395-411, 2010.

PESARAN, M. H.; POTTER, S. M. Nonlinear dynamics and econometrics: an introduction. Journal of Applied Econometrics, v. 7, n. special, p. 1-7, 1992.

POTTER, S. M. A nonlinear approach to US GNP. Journal of Applied Econometrics, v. 10, n. 2, p. 109-125, 1995.

PRIESTLEY, M. Non-linear and non-stationary time series analysis. London: Academic Press, 1988.

ROGOFF, K. The purchasing power parity puzzle. Journal of Economic Literature, v. 34, n. 2, p. 647-668, 1996.

ROSSI, B. Confidence intervals for half-life deviations from purchasing power parity. Journal of Business 8 Economic Statistics, v. 23, n. 4, p. 432-442, 2006.

SANDBERG, R.; CHANGLI, He. A unified theoretical framework when testing the unit root hypothesis in STAR type of models. Stockholm, Sweden, May 2005. Available in: <http:// www.fe.ualg.pt/conf/urct/prog/ps2/p2013.pdf> . Access in: March 03, 2014.

SARNO, L. Nonlinear exchange rate models: a selective overview. Washington, DC, 2003. (IMF Working Paper WP/03/111).

SARNO, L.; TAYLOR, M. P. Purchasing power parity and the real exchange rate. IMF Staff Papers, v. 49, n. 1, p. 65-105, 2002.

SARNO, L.; TAYLOR, M. P.; CHOWDHURY, I. Nonlinear dynamics in deviations from the law of one price: a broad-based empirical study. Journal of International Money and Finance, v. 23, n. 1, p. 1-25, 2004. 
SCHEINKMAN, J. A. Nonlinearities in economic dynamics. The Economic Journal, v. 100, n. 400, conference, p. 33-48, 1990.

SHINTANI, M. A nonparametric measure of convergence towards purchasing power parity. Journal of Applied Econometrics, v. 21, n. 5, p. 589-604, 2006.

SOLLIS, R.; LEYBOURNE, S. J.; NEWBOLD, P. Tests for symmetric and asymmetric nonlinear mean reversion in real exchange rates. Journal of Money, Credit and Banking, v. 34, p. 686700, 2002.

STROGATZ, S. H. Nonlinear dynamics and chaos. New York: Perseus Books, 1994.

TAYLOR, A. A century of purchasing-power parity. Review of Economics and Statistics, v. 84, n. 1, p. 139-150, 2002.

. An empirical examination of long-run purchasing power parity using cointegration techniques. Applied Economics, v. 20, p. 1369-1381, 1988.

TAYLOR, A.; TAYLOR, M. The purchasing power parity debate. Journal of Economic Perspectives, v. 18, n. 4, p. 135-158, 2004.

TAYLOR, M.; SARNO, L. Nonlinear mean-reversion in real exchange rates: toward a solution to the purchasing power parity puzzles. International Economic Review, v. 42, p. 1015-1042, 2001.

TIAO, G.; TSAY, R. Some advances in non-linear and adaptive modeling in time series. Journal of Forecasting, v. 13, p. 109-131, 1994.

TONG, H. Non-linear time series. Oxford: Clarendon Press, 1990.

TONG, H.; LIM, K. Threshold autoregression, limit cycles and cyclical data (with discussion). Journal of the Royal Statistical Society, v. 42, p. 245-292, 1980.

TSAY, R. Nonlinearity tests for time series. Biometrika, v. 73, p. 461-466, 1986.

WILLIAMSON, J. Exchange rate economics. Washington, DC, 2008. (Working Paper Series WP 08-3).

WOOLDRIDGE, J. M. Introductory econometrics: a modern approach. Mason, Ohio: Thomson South-Western, 2003. 


\section{Appendix A - Path of the Real Effective Exchange Rate and their Skeletons}

Figure 1 - Path of real effective exchange rate: sampled countries
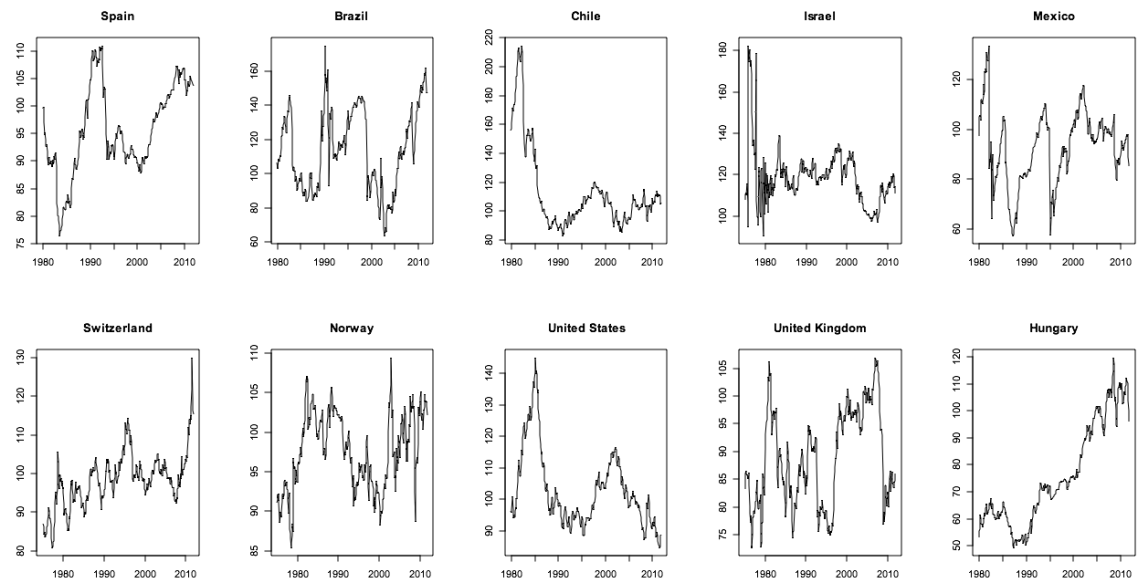

Source: Author's elaboration.

Figure 2 - Path of long run real exchange rate generated by the skeletons from fitted models
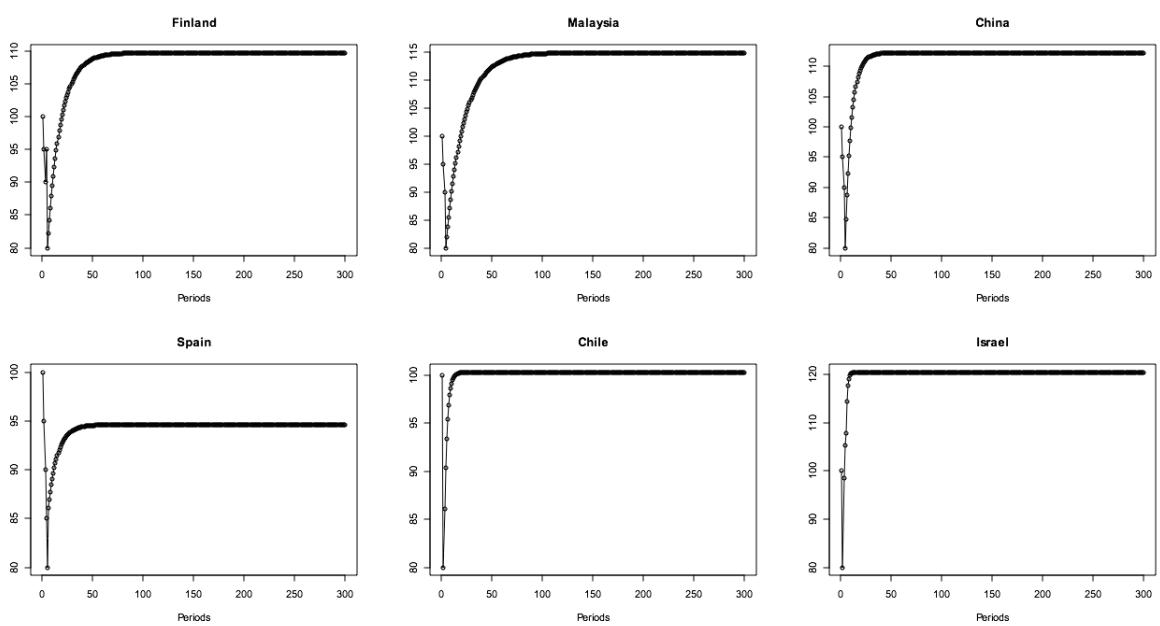

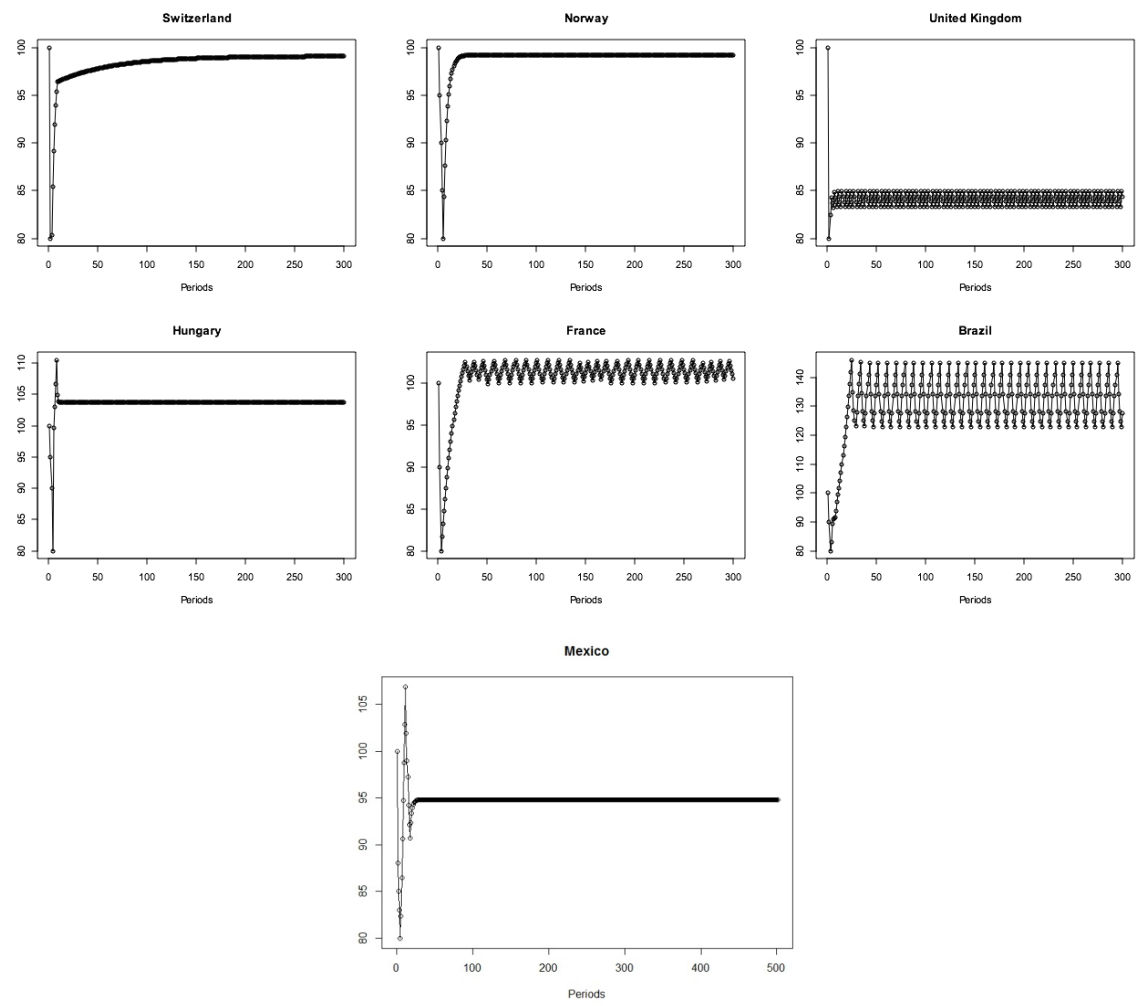

Source: Author's elaboration.

Recebido em: 23/06/2016.

Aceito em: 20/02/2017. 